\title{
A Hora da Estrela entre a ficção e a realidade: ou o trágico em Macabéa
}

\author{
Rogério de Almeida \\ Prof. Faculdade de Educação - USP \\ rogerioa@usp.br
}

Fábio Takao Masuda

Doutorando História Social - USP fabio.masuda@usp.br

Recebido em 30/06/2016. Aprovado em 14/11/2016.

Como citar este artigo: Almeida, Rogério e Masuda, Fábio Takao. "A Hora da Estrela entre a ficção e a realidade: ou o trágico em Macabéa”. Intelligere, Revista de História Intelectual, São Paulo, v. 3 , n 1 [4], p. 31-41. 2017. ISSN 2447-9020. Disponível em < http://revistas.usp.br/revistaintelligere $>$. Acesso em dd/mm/aaaa.

Resumo: Explicitaremos as relações entre ficção e história, tendo como objeto $A$ Hora da Estrela, de Clarice Lispector. Tal escolha se deve pelo fato da obra clariceana ser caracterizada como intimista, embora acreditemos que seja possível compreender as consequências sociais acarretadas pelo processo de modernização no Brasil, ocorrido na segunda metade do século XX, através da análise não só da personagem Macabéa, como também do narrador Rodrigo S. M., de modo a situar a obra entre ficção e realidade. É nessa zona de indeterminação e ambivalência que se instaura o caráter trágico de Macabéa, ao afirmar a vida diante da morte.

Palavras-chave: $A$ hora da estrela, Clarice Lispector, ficção e história, Brasil republicano, modernização brasileira, pensamento trágico.

\section{"The Hour of the Star" between fiction and reality: or, the tragic in Macabéa}

\begin{abstract}
In this article, we explicitly analyze the relations between fiction and history in the novel A Hora da Estrela (The Hour of the Star) by Clarice Lispector. While the novel is often characterized as an intimate one, it is possible to understand the social consequences provoked by the modernization process in Brazil in the second half of the twentieth century through analysis not only of the principal character Macabéa, but also of the narrator Rodrigo S.M. In this way, one may situate the novel between fiction and reality. It is in this zone of indeterminacy and ambivalence that the tragic character of Macabéa is revealed, affirming life in the face of death.
\end{abstract}

Keywords: The Hour of the Star, Clarice Lispector, fiction and history, Republican Brazil, Brazilian modernization, tragic thought. 
A esta leitura entre os dados da realidade e suas representações é o que se chama de leitura do intervalo. O intervalo, portanto, não é um vazio: é antes aquele tempo/espaço em que a literatura se afirma como literatura sendo sempre mais do que literatura porque apontando para esferas do conhecimento a partir das quais o signo literário alcança a representação. ${ }^{1}$.

A hora da estrela, último livro publicado por Clarice Lispector, em 1977, representa, para alguns críticos, um momento de inflexão; já outros especialistas veem essa obra como o afunilamento da crítica social engendrada pela autora. Por um lado, é evidente que nesse romance há uma crítica aberta às desigualdades sociais encontradas no Brasil, diferença relevante em relação aos outros romances escritos por Clarice. De outro lado, não podemos encarar tal diferença como uma mudança radical no estilo dessa escritora, uma vez que a sua ficção narrativa é caracterizada pela epifania e pela polissemia ${ }^{2}$. Assim, o aspecto social está presente na obra clariceana, mesmo que em algumas obras isso ocorra com um grau de acentuação menor, pois, nestas, o que salta aos olhos é justamente a predominância de sua marca característica: o subjetivismo, a introspecção e o intimismo.

É nesse universo permeado de significados que se enquadra $A$ hora da estrela. Nela não há somente a narrativa da retirante nordestina Macabéa, mas também existem outros dois eixos narrativos, a saber, o vinculado ao próprio narrador, Rodrigo S. M., e os dilemas da própria escritura da narrativa. Tal complexidade assinala de maneira exemplar a forma da narrativa moderna. Com efeito, o primeiro eixo narrativo é constituído pela história da personagem Macabéa, a qual representa o resultado das políticas de exclusão social brasileira. Ela é signo do deslocamento do migrante diante da metrópole, apresentada em toda sua hostilidade. O segundo eixo é articulado pela crise identitário-existencial vivida pelo próprio narrador, Rodrigo S. M., que é assolado por um sentimento de responsabilidade pelas contradições sociais do país. Por fim, o terceiro eixo narrativo é um exercício de metalinguagem e é composto pela problemática da construção do enredo da vida de Macabéa. Desta maneira, o leitor também é levado a participar do ofício do escritor, na medida em que ele discute o seu trabalho, ou seja, o ato de escrever ficções. Assim sendo, "a posição do leitor restabelece o sentido de historicidade da produção e da fruição artística e a possibilidade de diálogo entre temporalidades, algo que o relativismo desmedido nega, ao refutar o cruzamento de experiências distintas"3. Logo, A hora da estrela, ao cruzar essas diferentes temporalidades, apresenta-se como um objeto privilegiado para a investigação das relações entre ficção e história.

Diante de tal configuração narrativa da obra, propusemo-nos a analisar o modo que o processo de aceleração da modernização do Brasil republicano ${ }^{4}$ comparece como um dado real

\footnotetext{
${ }^{1}$ João Alexandre Barbosa, A leitura do Intervalo (São Paulo: Iluminuras, 1990), 11.

${ }^{2}$ Neiva Pitta Kadota, A Tessitura Dissimulada: o social em Clarice Lispector (São Paulo: Estação Liberdade, 1997), 19.

3 Júlio Pimentel Pinto, A leitura e seus lugares (São Paulo: Estação Liberdade, 2004), 59.

${ }^{4} \mathrm{O}$ tema da modernização histórica no Brasil (grosso modo, esta periodização abarca o início dos anos de 1920 até o final da década de 1970), ou, se se preferir, quais são os sentidos para o termo "moderno" no Brasil, é tratado de diferentes ângulos e perspectivas de análise, precisamente, por causa da divergência ideológica, bem como da carga semântica, de caráter polissêmico, adquirida pela palavra modernização. Para muitos especialistas, houve de fato um forte sentimento de esperança e otimismo no progresso histórico durante tal período. Segundo Maria Arminda do Nascimento Arruda, Metrópole e cultura (Bauru, SP: EDUSC, 2001), 18-19: "Esse cenário pleno de ricas possibilidades encerrou tendências que se prolongarão no futuro, além de conter os germens de certas transformações históricas que ainda hoje se desdobram. No plano mais imediato das transformações em curso, a metamorfose foi identificada à ideia de progresso; no plano mais complexo, o progresso manifestava-se nos diferentes modos de reconhecimento do moderno. Modernização, Modernismo e Modernidade foram termos que por vezes se confundiam e, repetidas ocasiões, se distinguiam. De modo geral, Modernização referia-se ao aceleramento das mudanças urbano- industriais, à diversificação dos padrões de consumo, à alteração nas formas de comportamento que passaram a se guiar por princípios semelhantes aos vigentes nos países desenvolvidos". Já para Fernando Antonio Novais e João Manuel Cardoso de Mello, "Capitalismo tardio e sociabilidade moderna". In: História da vida privada no Brasil: contrastes da intimidade contemporânea, org. Lilia Moritz Schwarcz (São Paulo: Companhia das Letras, 1998), 560: “Os mais velhos lembram-se muito bem, mas os mais moços podem acreditar: entre 1950 e 1979, a sensação dos brasileiros, ou de grande parte dos brasileiros, era a de que faltava dar uns poucos passos para finalmente nos tornarmos uma nação moderna. Esse alegre otimismo, só contrariado em alguns
} 
que contamina o texto ficcional e dele participa sem que seja obrigatoriamente descrito e caracterizado, mas contraparte da relação indissociável dos três eixos narrativos e seus pontos de intersecção: o da diegese ${ }^{5}$, com foco em Macabéa, o das reflexões do narrador sobre ela e o da construção do enredo por parte do leitor ${ }^{6}$. Não obstante, recusaremos a ideia de que o texto literário é um mero espelho da realidade ou de que não haja distinção entre a ficção e a escrita da história. Dada a tênue fronteira entre ficção e história, cujos espaços por vezes se sobrepõem, nos instauraremos nessa zona mista, intercambiável. Deste modo, o romance ficcional opera para além da literatura, que passa, necessariamente, pela ideia de "leitura do intervalo", como menciona João Alexandre Barbosa na epígrafe. Essa dimensão intervalar da literatura deve ser entendida como um momento de (des)encontro, tendo em vista a matéria histórica que há de comum entre a narrativa ficcional e o próprio processo histórico em que o autor está inserido. Não é o caso de conjecturar uma visão determinista, mas sim de localizar o conteúdo histórico por meio da contaminação recíproca dos elementos diegéticos, próprios do universo literário, e dos dados extraliterários, próprios do campo da história. Assim, é possível apreender as imbricações existentes entre a literatura e a história, justamente, porque "aquilo que se lê na obra literária é sempre mais do que literatura". Isso significa, de acordo com Barbosa, que no "intervalo" da literatura ocorre a confluência e o afunilamento das significações interdisciplinares, as quais levam à expansão dos significados das representações literárias. É esse movimento unificador dos referenciais internos e externos da leitura que provoca dificuldade de definir as distinções entre história e ficção. Desta forma, os debates em torno das distinções e das semelhanças entre as narrativas ficcionais e as narrativas históricas são variados, complexos e, por isso, permanecem inconclusos. Porém, é nesta tensão, bem como nesta zona de indeterminação e ambivalência "em que vejo poder ser percebida a interdisciplinaridade, a de uma saída do texto para um retorno fertilizador a ele, só pode ser descrita como uma estratégia de apreensão daquele movimento de configuração do signo poético"8. Nesse sentido, $A$ hora da estrela nos servirá como objeto desse exercício, uma vez que Antonio Candido reconhece na obra de Clarice Lispector "uma forma de conhecimento do mundo e das ideias". Por sua vez, Sérgio Buarque de Holanda salientou o seguinte:

Embora orientada em sentido diverso, a tentativa da sra. Clarice Lispector funda-se no mesmo empenho de dar voz articulada às mudanças por vezes radicais que se vão operando na condição e na consciência dos homens. E funda-se também na sua ambição de se apropriar de uma forma — uma técnica - mais em consonância com os temas abordados do que o são os recursos tradicionais da ficção, nascidos e sancionados em épocas de mais aparente estabilidade ${ }^{10}$.

As consequências da insígnia modernização brasileira: Macabéa - a "incompetente para a vida"11

rápidos momentos, foi mudando a sua forma. $\mathrm{Na}$ década dos 50 , alguns imaginavam até que estaríamos assistindo ao nascimento de uma nova civilização nos trópicos, que combinava a incorporação das conquistas materiais do capitalismo com a persistência dos traços de caráter que nos singularizavam como povo: a cordialidade, a criatividade, a tolerância. De 1967 em diante, a visão de progresso vai assumindo a nova forma de uma crença na modernização, isto é, de nosso acesso iminente ao 'Primeiro Mundo'. Havia certamente bons motivos para afiançar o otimismo. A partir dos anos 80 , entretanto, assiste-se ao reverso da medalha: as dúvidas quanto às possibilidades de construir uma sociedade efetivamente moderna tendem a crescer e o pessimismo ganha, pouco a pouco, intensidade".

${ }^{5}$ A diegese é compreendida como a realidade definida e representada pela narração como um mundo existente. Cf. Angélica Soares, Gêneros Literários (São Paulo: Ática, 2007), 44

${ }^{6}$ Cf. Wolfgang Iser, "El Proceso de Lectura: enfoque fenomenológico" In: Estética de la recepción (Madrid: Arco/Libros, 1987), 149-164.

7 João Alexandre Barbosa, A leitura do Intervalo, 15.

${ }^{8}$ Ibid, 31.

${ }^{9}$ Antonio Candido. "No raiar de Clarice Lispector”. In: Vários Escritos (São Paulo: Livraria Duas Cidades, 1977$), 126$.

${ }^{10}$ Sérgio Buarque de Holanda, O espírito e a letra: estudos de crítica literária, 1947- 1958, vol. II (São Paulo: Companhia das Letras, 1996), 208.

${ }^{11}$ Clarice Lispector, A bora da estrela (Rio de Janeiro: Rocco, 1998), 24. 
Como já foi dito acima, Macabéa é uma retirante nordestina que perdeu seus pais muito cedo, quando tinha apenas dois anos de idade, "lá" no sertão de Alagoas. Eles haviam falecido de "febres ruins", então ela foi criada em Maceió pelo único parente que tinha, uma tia beata. Esta lhe imputou uma criação violenta, opressora e castradora, não apenas no âmbito físico como também psicológico. A tia "dava sempre com os nós dos dedos na cabeça de ossos fracos por falta de cálcio [...]" para "evitar que a menina viesse um dia a ser uma dessas moças que em Maceió ficavam nas ruas de cigarro aceso esperando homem"12. Já adulta, com seus dezenove anos, migrou junto com a sua tia repressora para o Rio de Janeiro, "ignora-se o por quê" 13 . Contudo, mesmo com essa afirmação de Rodrigo S. M. de ignorar o porquê, é possível elaborar uma hipótese sobre a motivação de tal mudança, ao menos por parte da tia, pois Macabéa "não se conhece senão através de ir vivendo à toa"14: a tentativa de alcançar melhores condições de vida em relação as quais elas tinham na capital alagoana, mais precisamente, uma fuga da miséria a que estavam submetidas. A situação se tornou um clichê, entretanto, o fato é que Macabéa e sua tia representam os milhões de pessoas que fizeram parte de uma estatística espantosa, assim como a própria Clarice Lispector, que, por outros motivos, também se transferiu para o Rio de Janeiro em 1935, até então capital federal, junto com sua família:

Foi assim que migraram para as cidades, nos anos 50, 8 milhões de pessoas (cerca de 24\% da população rural do Brasil em 1950); quase 14 milhões, nos anos 60 (cerca de 36\% da população rural de 1960); 17 milhões, nos anos 70 (cerca de $40 \%$ da população rural de 1970). Em três décadas, a espantosa cifra de 39 milhões de pessoas! 15

Com efeito, a representação de tal estatística ocorre na "dimensão intervalar" da literatura, trata-se da "saída do texto para um retorno fertilizador a ele", na prerrogativa de Barbosa e no reconhecimento de que nenhum texto está isento a seu contexto. Contudo, essa relação não é simplesmente de correspondência entre os dados da realidade e os signos poéticos, já que

A verdade literária é uma, a verdade histórica, outra. Mas, mesmo que esteja repleta de mentiras - ou melhor, por isso mesmo - , a literatura conta uma história que a história, escrita pelos historiadores, não sabe nem pode contar. Porque as fraudes, os enganos e exageros da literatura narrativa servem para expressar verdades profundas e inquietantes, que somente dessa maneira enviesada vêm à luz ${ }^{16}$.

Assim, Macabéa foi trazida pela tia até o Rio de Janeiro, uma "cidade toda feita contra ela"17. E será que ela superará essas adversidades como fizeram os guerreiros Macabeus do Antigo Testamento, que são uma referência intertextual da qual deriva o nome da retirante? Infelizmente sabemos que não, pois essa é uma referência irônica, uma vez que a jovem nem tinha consciência de sua má sorte, tampouco das condicionantes históricas que a insígnia do processo modernizador brasileiro acarretava na vida dos migrantes como ela. Verdade esta que, por outro lado, era bem conhecida de Rodrigo S. M., como arrolada em uma das justificativas que dá para escrever a

\footnotetext{
${ }^{12}$ Clarice Lispector, $A$ hora da estrela, 28.

${ }^{13}$ Ibid, 30 .

${ }^{14}$ Ibid, 15.

${ }^{15}$ Fernando Antonio Novais e João Manuel Cardoso de Mello, "Capitalismo tardio e sociabilidade moderna”. In: História da vida privada no Brasil: contrastes da intimidade contemporânea, org. Lilia Moritz Schwarcz (São Paulo: Companhia das Letras, 1998), 581.

${ }^{16}$ Mário Vargas Llosa, A verdade das mentiras (São Paulo: Arx, 2004), 20.

${ }^{17}$ Clarice Lispector, $A$ bora da estrela, 15.
} 
narrativa ficcional de Macabéa: "Por que escrevo? Antes de tudo porque captei o espírito da língua e assim às vezes a forma é que faz o conteúdo. Escrevo, portanto, não por causa da nordestina, mas por motivo de 'força maior', como se diz nos requerimentos oficiais, por 'força de lei'"18. Sua reflexão é ambivalente, pois a "força maior" que o leva a escrever incide tanto sobre a matéria de sua escrita, a condição social de "sua" personagem, quanto a uma dimensão existencial, de quem capta o "espírito da língua", algo que se aproxima da noção deleuziana de que a escrita literária cria uma espécie de língua dentro da língua, um modo particular de se expressar, todavia que não é restrito a um sujeito:

De fato, o que produz enunciados em cada um de nós não se deve a nós como sujeitos, mas a outra coisa, às multiplicidades, às massas e às matilhas, aos povos e às tribos, aos agenciamentos coletivos que nos atravessam, que nos são interiores e que não conhecemos porque fazem parte de nosso próprio inconsciente. ${ }^{19}$

Neste sentido, Rodrigo escrevia também por sentir-se de alguma maneira responsável pela condição de Macabéa e, ao mesmo tempo, indignado diante da insultuosa desigualdade social existente no Brasil (não como sujeito - efetivamente inexistente, dada sua condição ficcional - mas como "agenciamento coletivo"), visto que essa última é uma consequência direta, dentre outros fatores, da forma como as camadas dirigentes conduziram a passagem do fim do século XIX aos anos de 1970. Claro que os mecanismos de exclusão variaram ao longo de tal período, porém, essa transição manteve excluídos setores historicamente marginalizados. Exatamente por isso o narrador afirma, logo em seguida:

$\mathrm{E}$ eis que fiquei receoso quando pus palavras sobre a nordestina. E a pergunta é: como escrevo? [...] Antecedentes meus do escrever? Sou um homem que tem mais dinheiro do que os que passam fome, o que faz de mim de algum modo um desonesto. E só minto na hora exata da mentira. Mas quando escrevo não minto. Que mais? Sim, não tenho classe social, marginalizado que sou. A classe alta me tem como um monstro esquisito, a média com desconfiança de que eu possa desequilibrá-la, a classe baixa nunca vem a $\operatorname{mim}^{20}$.

O narrador expressa uma angustiada crise existencial, também ambivalente, posto que se vê forçado a lidar com sua condição de narrador, uma entidade ficcional criada para incorporar a identidade de um escritor, bem como, dado o ofício de escritor, com sua condição social, independentemente de sua situação financeira e da comercialização de sua obra. Isso acontece, pois Rodrigo S. M. sabe que, independente de sua glória pessoal, ele é "um homem que tem mais dinheiro do que os que passam fome" e, por conseguinte, tem um nível de vida melhor do que a maioria da população (ele pode usar seu tempo para escrever em vez de encontrar meios de subsistência). Isso demonstra a dificuldade dos escritores em representar o "outro"21, que nesse caso é o pobre, o miserável. Além disso, se por um lado Rodrigo se identifica com tal contradição histórica, por outro não pode ser aceito por nenhuma classe social, pois efetivamente, como escritor, não pertence a nenhuma. Sua condição é a de quem, participando da sociedade, está ao mesmo tempo fora, uma espécie de "monstro esquisito", visto "com desconfiança" por sua existência circunscrita à sua escrita. E sabemos que, quando escreve, não mente. Por isso, Rodrigo

${ }^{18}$ Ibid, 18.

${ }^{19}$ Roberto Machado, Deleuze: a arte e a filosofia (Rio de Janeiro: Jorge Zahar, 2009), 216.

${ }^{20}$ Clarice Lispector, A bora da estrela, 18-19.

${ }^{21}$ Luís Bueno, "Os três tempos do romance de 30", Teresa: revista de literatura brasileira (São Paulo: Editora 34), n³, 2003, 263. 
tenta resolver essa contradição entre o intelectual e o trabalhador por meio da negatividade: "Eu não sou um intelectual, escrevo com o corpo"22.

Em meio a tantas angústias, ouve-se então o grito desesperado de Clarice, que procura dar vazão ao seu sentimento de responsabilidade por meio do narrador fictício Rodrigo S. M. ${ }^{23}$, como se observa na declaração da própria Clarice, após ganhar um prêmio da Fundação Cultural do Distrito Federal no valor de setenta mil cruzeiros, em 1976, pelo conjunto de sua obra: "Desde que recebi a notícia não consigo pensar senão nisto: crianças morrem de fome, crianças mortas de fome. Se eu doasse o prêmio para as crianças carentes os adultos ficariam com o dinheiro"24. Essas poucas palavras sintetizam visivelmente a enorme aflição que percorria a existência de Clarice, já que ela tinha plena consciência de que "não há documento da cultura que não seja ao mesmo tempo um documento da barbárie. E, assim como a cultura não é isenta de barbárie, não o é, tampouco, o processo de transmissão de cultura" 25 . Portanto, neste intenso momento de sua vida, a existência de Clarice foi permeada por essa responsabilidade social - preocupação com as "crianças carentes" - e, ao mesmo tempo, com a descrença nos dirigentes - "os adultos ficariam com o dinheiro". E tal descrença, a partir do golpe de 1964, intensifica-se cada vez mais e tem o seu ápice no ano de 1979, que demarca o "fechamento" de um processo histórico, pois:

a vida cultural brasileira passava cada vez mais a ser orientada pelo e para o mercado, cuja natureza desagregadora, do ponto de vista sociocultural, [...] não favorecia a geração de projetos e debates, nem estimulava ações mais sistemáticas de intervenção político-cultural por parte dos grupos sociais mais tradicionalmente ligados às práticas culturais ${ }^{26}$.

Essa figura do intelectual impotente não era uma novidade, haja vista a tamanha dificuldade da geração intelectual de 1870, que teve em Machado de Assis seu maior e mais cético expoente. Muitos em sua época acreditaram que o fim da escravidão e o advento do regime republicano, mais tarde visto de perto por Euclides da Cunha e Lima Barreto, proporcionassem condições para que houvesse uma distribuição de renda mais justa e, consequentemente, uma sociedade economicamente mais igualitária. No entanto, tal esperança foi abortada. Nesse sentido, o historiador Nicolau Sevcenko aponta que tanto o projeto literário de Lima Barreto quanto o de Euclides da Cunha constituem alternativas distintas frente à paisagem da Belle Époque brasileira e das terríveis contradições da Primeira República do Brasil, caracterizada por Lima Barreto como a "República dos Bruzundangas", "espécies de sociedades bizarras, onde os valores e as referências operavam às avessas"27. "Às avessas" porque, embora o regime político tenha mudado, a arquitetura da exclusão foi inteiramente mantida, ou seja, a reiteração da desigualdade social se tornaria não só a marca da Primeira República como também dos demais regimes republicanos instaurados no Brasil ao longo da história.

De um lado ocorreu uma modernização do palco político, de outro as atuações desempenhadas nele continuaram extremamente arcaicas. Por isso, Rodrigo S. M., ciente de todo esse processo histórico, representa o intelectual brasileiro impotente, descrente, frustrado. Já Macabéa constitui o retrato de toda aquela massa de pessoas alijadas da modernização conservadora e excludente implantada no solo brasileiro. Com efeito, o que resta a essa personagem é somente ser "incompetente para a vida".

${ }^{22}$ Clarice Lispector, $A$ bora da estrela, 16.

${ }^{23}$ O biógrafo de Clarice nos autoriza a reconhecer na voz do narrador sua própria voz: "por trás dele Clarice Lispector é ainda mais visível do que de costume”. Benjamin Moser, Clarice, uma biografia (São Paulo: Cosac Naif, 2009), 543.

${ }^{24}$ Teresa Montero, "Diálogos possíveis com Clarice Lispector", Revista Unisinos-IHUONLINE.

www.unisinos.br/ihuonline/uploads/edicoes/1184615898.53word.doc. [Acessado em 16 de novembro, 2008 ]

${ }^{25}$ Walter Benjamin, "Sobre o conceito de história". In: Obras Escolbidas I (São Paulo: Brasiliense, 1985), 225.

${ }^{26}$ Marcos Napolitano, "Cultura, modernidade e brasilidade (1922-1979)". In: SZESZ, C. M., (et al) Portugal-Brasil no século XX: sociedade, cultura e ideologia v. 1 (Bauru: EDUSC, 2003), 299.

${ }^{27}$ Nicolau Sevcenko, Literatura como missão: tensões sociais e criação cultural na Primeira República. $2^{\mathrm{a}}$ ed. (São Paulo: Companhia das Letras, 2003), 224. 


\section{Sob o olhar petrificante}

Logo ao chegar ao "inacreditável Rio de Janeiro", a tia moralista consegue um emprego, ou melhor, um subemprego de datilógrafa para a sua sobrinha Macabéa. Foi o último ato em vida daquela e, agora, esta passa a morar "numa vaga de quarto compartilhado com mais quatro moças balconistas das Lojas Americanas"28. É o início do estrelato de Macabéa, que tem como espaço a grande metrópole carioca, onde tudo foi feito contra ela.

Nesse ponto, encontramos, mais uma vez, a presença de Clarice e sua íntima relação com a personagem Macabéa. Isso ocorre na medida em que esta última é fruto da observação da matéria histórica que passou aos olhos da escritora, como esclarece a própria Clarice Lispector na famosa entrevista concedida ao jornalista Júlio Lerner, da TV Cultura, em fevereiro de 1977. Nessa entrevista, Clarice diz que, ao passear por uma feira no bairro de São Cristóvão, feita nos moldes das que existem no Nordeste, avistou "uma moça nordestina, de Alagoas, tão pobre que só comia cachorro-quente" ${ }^{29}$. Essa moça é transfigurada em Macabéa n' $A$ hora da estrela, cuja narrativa não se resume apenas à sua condição social, como confirma a própria Clarice: "A história não é só isso, não. A história é de uma inocência pisada, de uma miséria anônima"30.

Miséria que é endêmica e, no caso de "Maca", atingia-a em todos os níveis de existência. Como sabemos, ela já nasceu subnutrida e sentiu na pele a penúria do mundo da seca, onde os coronéis mandam e desmandam, onde a arbitrariedade e a violência são cotidianas. Quando adulta, também não consegue preencher os vazios de sua vida e tampouco é capaz de fugir dos atos de violência; pelo contrário, ocorre um aprofundamento das suas carências, posto que chega a uma cidade onde é uma estranha e uma prisioneira da sua condição. "Macabéa, feita de contradições, reúne em si a pobreza econômica, física, alimentar e intelectual, de saúde, de costumes, de lazer, sempre segundo os padrões dominantes. Além disto é mulher, meio mestiça na raça e na religião" 31 . O que mais aterroriza é sua insensibilidade, sua incapacidade de tomar consciência de sua condição, não só social como também existencial.

Mesmo com a sua precária ocupação como datilógrafa de um escritório, Macabéa não consegue afirmar-se como sujeito e, tampouco, identificar-se com um determinado grupo social: “... é tão tola que às vezes sorri para os outros na rua. Ninguém lhe responde ao sorriso porque nem ao menos a olham"32, dado que a "vida é assim: aperta o botão e a vida acende. Só que ela não sabia qual era o botão de acender. Nem se dava conta de que vivia numa sociedade técnica onde ela era um parafuso dispensável" 33 . Portanto, Macabéa era oca como o modo de vida que passava a vigorar, no Brasil, em escala cada vez maior, a partir dos anos de 1940: "Creio que é somente na década de 40 que se pode considerar seriamente a presença de uma série de atividades vinculadas à cultura popular de massa no Brasil"34.

A indústria cultural e a sociedade de consumo estão presentes em cada página d'A hora da estrela, contudo, não como um espelhamento do real, e sim por uma contaminação recíproca entre a ficção e a história, dada a porosidade em tais narrativas. Então, lembraremos das referências mais do que concretas, como o pseudopatrocínio da Coca-Cola; a alimentação americanizada à base de cachorro quente e refrigerante; as Lojas Americanas nas quais trabalham as amigas de quarto de

\footnotetext{
${ }^{28}$ Clarice Lispector, $A$ bora da estrela, 30

${ }^{29}$ Nádia Battella Gotlib, "Macabéa e as mil pontas de uma estrela". In: Personae: grandes personagens da literatura brasileira. orgs. MOTA, L. D. e ABDALA JR., Benjamin (São Paulo: Editora SENAC, 2001), 313.

${ }^{31}$ Suzi Frankl Sperber, “Jovem com ferrugem”. In: Os pobres na Literatura Brasileira, org. Roberto Schwarz (São Paulo: Editora Brasiliense, 1983), 155

${ }^{32}$ Clarice Lispector, A hora da estrela, 15-16.

${ }^{33}$ Ibid, p. 29.

${ }^{34}$ Renato Ortiz, A moderna tradição brasileira (São Paulo: Editora Brasiliense, 2001), 38.
} 
Macabéa; os ícones do cinema norte-americano Marylin Monroe e Greta Garbo; as informações inúteis da Rádio Relógio, que dava "hora certa e cultura"; a publicidade, a qual aparecia na coleção de anúncios de jornais velhos recortados por Macabéa, cujo prazer era tão grande que os colava em um álbum: "havia um anúncio, o mais precioso, que mostrava em cores o pote aberto de um creme para pele de mulheres que simplesmente não eram ela"35.

De maneira geral, diante deste quadro social mais amplo, temos de um lado o mecanismo de massificação capitalista e, de outro, o arcaísmo nas relações sociais, forças que incidem na personagem Macabéa, espécie de síntese da condição dos menos favorecidos frente ao projeto modernizador-excludente, que encontrou seu auge na ditadura militar. Condição de deslocamento, pois "Maca" não se situa nas relações sociais tradicionais, tampouco nas relações da sociedade de consumo: não tem rosto, é massa; não tem valor social, é migrante, é nordestina, é datilografa, é parda, é mulher.

Esse é o drama de Macabéa, que não consegue criar vínculo identitário nem mesmo quando inicia um "namoro ralo" com o paraibano Olímpico de Jesus. Este é um "cabra safado", que trabalhava como operário de uma metalúrgica, emprego típico das grandes cidades que se industrializavam no centro-sul do Brasil. Embora também tenha vivenciado as mesmas mazelas que as estruturas sociais do sertão nordestino imputam aos seus habitantes, ele representa o outro lado dessa exclusão, visto que tinha muitas ambições na vida. Olímpico é o típico representante do trabalhador alienado - "o trabalho consistia em pegar barras de metal que vinham deslizando de cima da máquina para colocá-las embaixo, sobre uma placa deslizante. Nunca se perguntara por que colocava a barra embaixo" 36 - porém sabia muito bem o que queria ser: "um dia vou ser muito rico, disse ele que tinha uma grandeza demoníaca (...) e dissera que terminaria deputado pelo Estado da Paraíba" ${ }^{37}$.

Olímpico não mediu esforços e não teve escrúpulos para alcançar seus objetivos, tanto que os alcançou. Essa enorme cobiça representa o espírito arrivista e embrutecido que atinge parte dos que são excluídos desse processo modernizador. E tal ambição não é somente o simples desejo de sair das péssimas condições de vida a que estão submetidos, como também de fazer parte da cúpula do poder que usufrui os benefícios da exploração do trabalho: "ele não era inocente coisa alguma, apesar de ser uma vítima geral do mundo. Tinha, descobri agora, dentro de si a dura semente do mal, gostava de se vingar, este era seu grande prazer e o que lhe dava força de vida" 38 . No entanto, ele apreciava a vingança também porque o seu mundo se apresentava extremamente agressivo, ou seja, os seus encontros com a realidade não eram afetuosos e sensíveis, pelo contrário, eram hostis e brutais. Por isso, Rodrigo S. M., em seguida, logo o perdoa:

Ele tinha fome de ser outro. No mundo de Glória, por exemplo, ele ia se locupletar, o frágil machinho. Deixaria enfim de ser o que sempre fora e que escondia até de si mesmo por vergonha de tal fraqueza: é que desde menino na verdade não passava de um coração solitário pulsando com dificuldade no espaço. O sertanejo é antes de tudo um paciente. Eu o perdoo ${ }^{39}$.

Macabéa localiza-se na outra ponta desse processo, devido à sua singela ignorância. Ela é submetida por essa mesma marcha, todavia não ambiciona, não deseja, não expressa vontade. Já Olímpico é seduzido pelos jogos de representação enfeixados na sociedade de consumo, que "reforça a percepção e o sentimento da necessidade de ser incluído nesse espaço, sob pena de

\footnotetext{
${ }^{35}$ Clarice Lispector, $A$ bora da estrela, p. 38.

${ }^{36} \mathrm{Ibid}, 45$.

${ }^{37} \mathrm{Ibid}, 45$ e 47 (respectivamente).

${ }^{38} \mathrm{Ibid}, 47$.

${ }^{39}$ Ibid, 65-66.
} 
converter as perdas numa perda irreversível: a da própria humanidade, invalidada pela incompetência" 40 .

Não obstante, se o risco de Olímpico é perder sua humanidade por não participar da sociedade de consumo vendida pelos meios de comunicação em massa, ou por participar dela via um caminho brutal e desumanizador, já Macabéa não corre tal risco, pois não somente não deseja participar dessa sociedade como sequer reconhece em si uma humanidade. Macabéa não é desumana e sim inumana ou pré-humana. Resta-lhe, quando muito, sonhar com a humanidade dos outros. "Não se identificando a nada nem a ninguém que a circunde, sonha em tornar-se outra, iludindo-se com a fantasia de um dia vir a ser estrela de cinema, como Greta Garbo e, principalmente, Marylin Monroe"41. Não tendo nenhuma relação de sociabilidade com a qual se reconheça e, por conseguinte, se identifique, Macabéa se espelha na alteridade, representada pela cultura de massas. Assim, ela se tornará matéria completamente opaca, seca, dura, estática, inócua, sem rosto, em suma, uma pedra. Isso tudo porque foi abatida pelo olhar amaldiçoado e conservador da Medusa modernizadora. Por isso, Rodrigo S. M. afirma que estará "lidando com fatos como se fossem as irremediáveis pedras de que falei" ${ }^{42}$.

\section{Como disse Shakespeare, a vida "é uma história que conta o idiota, toda som e fúria, sem querer dizer nada"43}

Benjamin Moser registra que Clarice, por sugestão de Marina Colasanti e Affonso Romano de Sant'Anna, frequentava uma cartomante no bairro do Méier e, fazendo menção à entrevista concedida a Julio Lerner, resgata uma fala de Clarice que surgiu em uma de suas visitas à cartomante: "Ela disse várias coisas boas que iam acontecer e imaginei, quando tomei o táxi de volta, que seria muito engraçado se um táxi me pegasse, me atropelasse e eu morresse depois de ter ouvido todas essas coisas boas" 44 . É desse fato corriqueiro que nasce o final d'A Hora da Estrela, desse curto-circuito entre o desejo de acreditar e a impossibilidade de transpor o caráter trágico ${ }^{45}$ da existência. De acordo com Nietzsche, o trágico é a "fórmula da afirmação máxima, da plenitude, da abundância, um dizer sim sem reservas, até mesmo ao sofrimento, à própria culpa, a tudo o que é problemático e estranho na existência" ${ }^{46}$. Esse aspecto negativo da vida é constantemente observado ${ }^{47}$ pelo narrador Rodrigo S.M.: "Eu poderia resolver pelo caminho mais fácil, matar a menina-infante, mas quero o pior: a vida. (...) A vida é um soco no estômago.”48

${ }^{40}$ Marilena Chaui, “O Popular e a Massa”. In: Conformismo e resistência: aspectos da cultura popular no Brasil (São Paulo: Editora Brasiliense, 1986), 39.

${ }^{41}$ Gilberto Figueiredo Martins, "Alter(c)idades- um exercício de escalas. (Espaço público, modos de subjetivação e formas de sociabilidade na obra de Clarice Lispector)" (Tese de doutorado - FFLCH/USP. Departamento de Letras Clássicas e Vernáculas, 2002), 103.

42 Clarice Lispector, $A$ bora da estrela, 17.

${ }^{43}$ William Shakespeare, "Macbeth”. In: Tragédias e comédias sombrias: obras completas (Rio de Janeiro: Nova Aguilar, 2006$), 793$.

${ }^{44}$ Apud Benjamin Moser, Clarice, uma biografia, 549.

${ }^{45}$ Cabe aqui mencionar o trágico interpretado também como "avesso da modernidade", no sentido de um "refluxo do otimismo capitalista", o que contrasta com o processo de modernização. Cf. Aldo Nelson Bona e Hélio Sochodolak, "O trágico como avesso da modernidade". In: História e tragicidade, orgs. Hélio Sochodolak e Jair Antunes (São Paulo: Scortecci, 2010), 13- 14.

${ }^{46}$ Friedrich Nietzsche, Ecce homo. Como alguém se torna o que é (São Paulo: Companhia das Letras, 1995), 118.

${ }^{47} \mathrm{Da}$ mesma forma que a obra literária não é um mero espelho da realidade histórica, também se torna imprescindível frisar que, a partir da relação filosofia e literatura, não é frutífero instrumentalizar a literatura em função de conceitos da filosofia, ou, ainda, lançar mão de conceitos instrumentais da filosofia para subordinar a crítica de uma narrativa literária. Por isso, é preciso estar muito atento ao que Benedito Nunes escreveu acerca da sua própria experiência como professor de filosofia ao investigar a obra de Clarice Lispector: Benedito Nunes, "Filosofia e literatura". In: No tempo do niilismo e outros ensaios (São Paulo: Edições Loyola, 2012) 184- 185. "O primeiro risco a evitar é a busca de conceitos instrumentais na Filosofia para o exercício de uma pretensa Crítica Filosófica, que tentaria estudar a obra como a ilustração de verdades gerais. No primeiro estudo que escrevi sobre Clarice Lispector caí na sedutora armadilha dessa Crítica redutora, cujos passos exegéticos, muito esquemáticos, partem de uma analogia. Sobressaem nos contos e romances dessa autora graus de reflexividade dos personagens, que se enquadram nas categorias existenciais de mundo, intersubjetividade conflitante e náusea. Logo, bastaria elaborar a analogia para extrair da narrativa de Clarice Lispector uma conceptualística existencial ou, mais particularmente, existencialista [...] Eis o parco rendimento — ou rendimento nulo? — da Crítica desenvolvida como paráfrase filosófica. A ficção mesma da romancista, com seus procedimentos peculiares, da construção dos personagens ao aparato de sua linguagem, segundo a ligação característica entre história e o discurso que nessa ficção se efetua - tudo isso, que é propriamente literário, era como que suprimido e eliminado em proveito do 'substrato 
O que se passa, então, com Macabéa? Ela perde seu namorado Olímpico, que vê em Glória uma possibilidade de ascensão. Glória trabalhava com "Maca" e para compensar o roubo do namorado empresta-lhe dinheiro para uma visita à cartomante, a mesma que disse à Glória que Olímpico passaria a ser seu namorado. Madama Carlota põe as cartas para Macabéa e lhe diz que sua vida é horrível, entretanto, completou que a partir daí seria agraciada com um "maravilhoso destino". Tal previsão seria o casamento com um homem muito rico, louro e de "olhos azuis ou verdes ou castanhos ou pretos"49.

Macabéa estava espantada. Só então vira que sua vida era uma miséria. Teve vontade de chorar ao ver o seu lado oposto, ela que, como eu disse, até então se julgava feliz" [...] Sentia em si uma esperança tão violenta como jamais sentira tamanho desespero. Se ela não era mais ela mesma, isso significava uma perda que valia por um ganho. Assim como havia sentença de morte, a cartomante lhe decretara sentença de vida. Tudo de repente era muito e muito e tão amplo que ela sentiu vontade de chorar. Mas não chorou: seus olhos faiscavam como o sol que morria ${ }^{50}$.

Por meio da invenção do futuro ${ }^{51}$, a cartomante dá vida à Macabéa, transforma-a em humana, pois faz nascer nela desejo, vontade, alegria. Não foi a medicina que lhe permitiu viver, pelo menos, não a medicina praticada pelo "médico barato" indicado por Glória. "Esse médico não tinha objetivo nenhum. A medicina era apenas para ganhar dinheiro e nunca por amor à profissão nem a doentes. Era desatento e achava a pobreza uma coisa feia. Trabalhava para os pobres detestando lidar com eles" 52 . Pelo contrário, de forma paradoxal, como já anunciou Shakespeare, foram as palavras da cartomante, que deram "sentença de vida" à pobre nordestina e a libertaram do "limbo impessoal". Elas soaram como música na triste e silenciosa vida de uma jovem de quem foi retirado o direito ao grito. E, para Clarice, assim como para Nietzsche ${ }^{53}$, a música tem este incrível poder de promover o reconhecimento de si, de intensificar a vida, como ocorre no episódio em que Macabéa ouve Una Furtiva Lacrima, de Enrico Caruso, "fora a única coisa belíssima" 54 na vida de Macabéa, visto que foi capaz de sensibilizar sua alma e, por conseguinte, a fez chorar. Nesse sentido, logo na "Dedicatória" do livro, Clarice reverencia e dedica essa obra a Beethoven, a Bach, a Chopin, a Stravinsky, a Richard Strauss, a Debussy, a Marlos Nobre, a Prokofiev, a Carl Orff, a Schönberg e aos dodecafônicos. Essa longa lista tem uma justificativa: "todos esses que em mim atingiram zonas assustadoramente inesperadas, todos

filosófico’ da narrativa. Nos estudos posteriores, pude, felizmente, corrigir essa distorção, sob o foco prioritário da narrativa literária ajustado ao primado da consciência individual que marca o plano da criação mimética em Clarice Lispector. O 'substrato filosófico' não é, de modo algum, independente desse plano. Sem subordinar a obra examinada a conceitos instrumentais da Filosofia - o que força a instrumentalização da própria obra, convertida no reflexo de uma determinada concepção filosófica —, minha crítica se tornaria mais respeitosa da exigência de verdade”.

${ }^{48}$ Clarice Lispector, $A$ bora da estrela, 86.

${ }^{49}$ Ibid, p. 77.

${ }^{50}$ Ibid, p. 79.

${ }^{51} \mathrm{Da}$ mesma forma que a cartomante forneceu um sentido na vida de Macabéa, as perspectivas escatológicas do tempo sobre a história imputam uma visão linear de progresso inequívoco, de melhoria contínua, de salvação em relação ao passado. Segundo Nietzsche, trata-se do culto dos fatos, aquela história factual, que exerce o poder ao fazer previsões do futuro (como a cartomante d' $A$ bora da estrela, ou mesmo a ideologia da modernização). Com efeito, tal "poder da história", ao mesmo tempo em que produz sentidos, segurança e expectativas na crença de um futuro previsível, gera também culto, domínio e submissão. Friedrich Nietzsche, Segunda Consideração Intempestiva: da utilidade e desvantagem da bistória para a Vida. (Rio de Janeiro: Relume Dumará, 2003), 72-73: O “"poder da história” que praticamente converte todos os instantes em desguarnecida admiração ante os resultados positivos e conduz à idolatria do factual: para este culto, em geral, se treinou agora expressão mitologizante e, além disto, com todo o direito, bem alemã: 'ter em conta os fatos'. Mas quem aprendeu inicialmente a se curvar e a inclinar a cabeça diante do 'poder da história' acaba, por último, dizendo 'sim' a todo poder, balançando mecanicamente a cabeça como os chineses, quer se trate de um governo ou de uma opinião pública ou de uma maioria numérica, movimentando seus membros no exato compasso em que qualquer 'poder' puxa os fios. Se todo evento contém em si uma necessidade racional, todo acontecimento é a vitória do lógico ou da 'ideia' - então se ajoelhem depressa e louvem agora toda a escala dos 'eventos'!"

${ }^{52}$ Clarice Lispector, A hora da estrela, 67-68.

${ }^{53}$ Rosa Maria Dias, Nietəssche e a música. (São Paulo: Discurso Editorial; Ijuí, RS: Editora UNIJUÍ, 2005), 63-64.

${ }^{54}$ Clarice Lispector, A hora da estrela, p. 51. 
esses profetas do presente e que a mim me vaticinaram a mim mesmo a ponto de eu neste instante explodir em: eu" 55 .

Por outro lado, a música também anuncia a morte. É o que acontece, quando Macabéa é atropelada por um Mercedes amarelo, alegoria do processo modernizador. Ademais, ironicamente, a cartomante, ao errar a previsão, fornece-lhe o lindo som da vida que é seguido da morte. Esta é plangida pelo "som espichado e agudo" de um homem que tocava violino na esquina da rua em que Macabéa dá seus últimos suspiros de vida. Dessa forma, o destino de Macabéa só poderia ser este, o encontro com a vida, que é acompanhada da morte, pois essa última também é a libertação da miséria a que ela estava submetida e, mesmo após a tomada de consciência, ela não seria capaz de viver nessa cidade "toda feita contra ela". Por isso, o homem do violino acompanha essa história desde o começo e Rodrigo S. M. também o conhece: "Sei que quando eu morrer vou ouvir o violino do homem e pedirei música, música, música" ${ }^{56}$.

Ao fim e ao cabo, Macabéa cumpre o destino trágico de afirmar a vida diante do que é mais estranho na existência: "- ali deitada - teve uma úmida felicidade suprema, pois ela nascera para o abraço da morte”" ${ }^{7}$. Como aponta Claudio Dias G., a Tragédia é

orgulho e alegria que nasce mesmo da condição humana falha e do pior dos mundos, ao ofertar a arte como justificativa maior para a vida. Como bastião do sagrado, a Tragédia é um modo de ver e se aceitar incondicionalmente o destino e o mundo. É o afrontar o absurdo e a morte com o "amor fati" 58.

Isso nos obriga a reconhecer, como conclusão, que Clarice Lispector não se furtou a abordar problemas sociais importantes da história do Brasil, todavia recusou tomá-la como a única força definidora da realidade. Por meio de sua ficção, ou melhor, no espaço intervalar entre ficção e história, incrustou uma nordestina miserável não só na condição social, mas sobretudo existencial e, na impossibilidade de salvá-la das brutais consequências do processo modernizador brasileiro, tornou-a heroína trágica, não porque venceu a morte, mas justamente por ter celebrado a vida. É um instante fugaz, sem dúvida, muito distinto de todos os nãos que sua condição social lhe impingiu. No entanto, é paradoxalmente o instante mais intenso e pleno de toda sua vida. Não à toa, o livro termina com uma breve e contundente afirmação: "Sim" 59 .

\footnotetext{
${ }^{55}$ Ibid, 9.

${ }^{56} \mathrm{Ibid}, 82$.

${ }^{57} \mathrm{Ibid}, 84$.

${ }^{58}$ Claudio Dias G, Clarice Lispector \& Friedrich Nietæsche: um caso de amor fati (São Paulo: Tempo Brasileiro, 2012$), 50$.

${ }^{59}$ Clarice Lispector, A bora da estrela, 87.
} 